\title{
Erratum to: Long, titanium, cemented stems decreased late periprosthetic fractures and revisions in patients with severe bone loss and previous revision
}

Philippe Hernigou • Nicolas Dupuys • Jerome Delambre • Isaac Guissou • Alexandre Poignard • Jerome Allain •

Charles Henri Flouzat Lachaniette

Published online: 9 October 2014

(C) SICOT aisbl 2014

Erratum to: International Orthopaedics (SICOT)

DOI 10.1007/s00264-014-2528-2

The original publication of this article inadvertently contained a mistake in the presentation of the name of the authors.

The correct presentation is given above.

The online version of the original article can be found at http://dx.doi.org/ 10.1007/s00264-014-2528-2.

P. Hernigou $(\bowtie)$

Orthopedic Surgery, Hôpital Henri Mondor, Creteil, France

e-mail: philippe.hernigou@wanadoo.fr

N. Dupuys $\cdot$ J. Delambre $\cdot$ I. Guissou $\cdot$ A. Poignard $\cdot$ J. Allain •

C. H. Flouzat Lachaniette

University Paris East, Paris, France 